${ }^{1}$ Institut für Allgemeine Mikrobiologie, Am Botanischen Garten 1-9, 24118 Kiel, Germany

2 DSMZ Braunschweig, Mascheroder Weg 1b, 38124 Braunschweig, Germany

\section{Hydrogenothermus marinus gen. nov., sp. nov., a novel thermophilic hydrogen-oxidizing bacterium, recognition of Calderobacterium hydrogenophilum as a member of the genus Hydrogenobacter and proposal of the reclassification of Hydrogenobacter acidophilus as Hydrogenobaculum acidophilum gen. nov., comb. nov., in the phylum 'HydrogenobacterlAquifex'}

\author{
Rüdiger Stöhr, ${ }^{1} \dagger$ Arne Waberski, ${ }^{1}$ Horst Völker, ${ }^{1}$ Brian J. Tindall ${ }^{2}$ \\ and Michael Thomm ${ }^{1}$ \\ Author for correspondence: Michael Thomm. Tel: +49 431880 4330. Fax: +49431880 2194. \\ e-mail:mthomm@ifam.uni-kiel.de
}

\begin{abstract}
A novel thermophilic, hydrogen-oxidizing bacterium, VM1' ${ }^{\top}$, has been isolated from a marine hydrothermal area of Vulcano Island, Italy. Cells of the strain were Gram-negative rods, 2-4 $\mu \mathrm{m}$ long and 1-1.5 $\mu \mathrm{m}$ wide with four to seven monopolarly inserted flagella. Cells grew chemolithoautotrophically under an atmosphere of $\mathrm{H}_{2} / \mathrm{CO}_{2}(80: 20)$ in the presence of low concentrations of $\mathrm{O}_{2}$ (optimum 1-2\%). Carbohydrates and peptide substrates were not utilized, neither for energy generation nor as a source of cellular carbon. Growth of VM1' occurred between 45 and $80^{\circ} \mathrm{C}$ with an optimum at $65^{\circ} \mathrm{C}$. Growth was observed between $\mathrm{pH} 5$ and 7. NaCl stimulated growth in the range 0.5-6\% with an optimum at 2-3\%. Hydrogen could not be replaced by elemental sulfur or thiosulfate as electron donors. Nitrate and sulfate were not used as electron acceptors. The major respiratory lipoquinone was a new menathioquinone. Analysis of the fatty acids of $\mathrm{VM1}^{\top}$ revealed straight-chain saturated $\mathrm{C}_{18: 0}$ and the unsaturated $C_{18: 1} \omega 9 \mathrm{C}$ and $C_{20: 1} \omega 9 \mathrm{c}$ as major components. The $G+C$ content of the total DNA was $43 \mathrm{~mol} \%$. Phylogenetic analysis placed strain VM1' near the members of the genera Hydrogenobacter, Thermocrinis and Aquifex on a separate deep-branching phylogenetic lineage. Therefore, it is proposed that strain VM1 ${ }^{\top}\left(=\right.$ DSM $\left.^{12046^{\top}}=\mathrm{JCM}^{\mathrm{N}} 10974^{\top}\right)$ represents a novel species within a new genus, for which the name Hydrogenothermus marinus gen. nov., sp. nov., is proposed. In addition, it is shown that Calderobacterium hydrogenophilum should be transferred to the genus Hydrogenobacter; the name Hydrogenobacter hydrogenophilus comb. nov. (DSM 2913 $=\mathrm{JCM} 8158^{\mathrm{T}}$ ) is proposed for this organism. Furthermore, on the basis of 16S rRNA sequence analysis, Hydrogenobacter acidophilus is only distantly related to Hydrogenobacter species. Owing to this finding and its growth at low $\mathrm{pH}$, the name Hydrogenobaculum acidophilum gen. nov., comb. nov., is proposed for Hydrogenobacter acidophilus. The type strain is JCM $8795^{\top}$ (= DSM 11251').
\end{abstract}

Keywords: hydrogen oxidation, thermophilic bacteria, Aquifex, Hydrogenobacter

† Present address: Institut für Meereskunde, Düsternbrooker Weg 20, 24105 Kiel, Germany.

The GenBank accession number for the $16 \mathrm{~S}$ rDNA sequence of strain VM1 ${ }^{\top}$ is AJ292525. 


\section{INTRODUCTION}

When Aquifex pyrophilus was described (Huber et al., 1992; Burggraf et al., 1992), a new phylum of the Bacteria was found that represented the deepest branching of the bacterial kingdom. Aquifex pyrophilus was characterized by its hyperthermophilic and chemolithoautotrophic metabolism, yielding energy from the oxidation of molecular hydrogen. Other thermophilic, hydrogen-oxidizing bacteria were found to be related. Hydrogenobacter thermophilus (Kawasumi et al., 1984) and Calderobacterium hydrogenophilum (Kryukov et al., 1983) also could be grouped together within the order 'Aquificales' (Huber et al., 1998).

While Aquifex pyrophilus was isolated from a marine geothermally heated area of the Kolbeinsey Ridge, members of the genera Hydrogenobacter, Calderobacterium and Thermocrinis (Huber et al., 1998) were isolated from freshwater habitats. The only marine species of the genus Hydrogenobacter reported so far is 'Hydrogenobacter halophilus', which was isolated from a marine hot spring (Nishihara et al., 1990). With respect to the optimal temperature of growth, members of the genera Aquifex and Thermocrinis are hyperthermophiles, showing optimal growth at $85^{\circ} \mathrm{C}$. Representatives of the genera Hydrogenobacter and Calderobacterium show optimal growth around $70{ }^{\circ} \mathrm{C}$. They do not grow at $85^{\circ} \mathrm{C}$. Here, we describe a new strain of marine origin with an even lower optimal growth temperature, of $65^{\circ} \mathrm{C}$, representing a new phylogenetic lineage within the phylum 'Hydrogenobacter/Aquifex'.

\section{METHODS}

Origin of samples. Strain $\mathrm{VM} 1^{\mathrm{T}}$ was isolated from a marine water sample that also contained sediment. The sample was taken from a geothermally heated shallow area at Vulcano beach, 3-4 m from the shore. The temperature of the sample was $83{ }^{\circ} \mathrm{C}$. The sample was collected with a $20 \mathrm{ml}$ syringe and was transferred to a $20 \mathrm{ml}$ tube containing a drop of resazurin solution $(0 \cdot 1 \%)$. The tube was sealed with a rubber stopper and reduced by adding a spatula-tip amount of dithionite to protect the sample from oxygen, as we planned initially to isolate anaerobes.

Culture media. Modified marine medium described by ZoBell (1941) was used for the isolation of $\mathrm{VM} 1^{\mathrm{T}}$. This medium contained $\left(\mathrm{g} \mathrm{l}^{-1}\right)$ : Bacto yeast extract, $1 \cdot 0$; Bacto peptone, $5 \cdot 0 ; \mathrm{NaCl}, 19 \cdot 4 ; \mathrm{MgCl}_{2} \cdot 6 \mathrm{H}_{2} \mathrm{O}, 12 \cdot 6 ; \mathrm{NaHCO}_{3}$, $0 \cdot 16 ; \mathrm{Na}_{2} \mathrm{SO}_{4}, 3 \cdot 24 ; \mathrm{KCl}, 0 \cdot 56$; elemental sulfur, $2 \cdot 0$; resazurin $(0 \cdot 1 \%), 1.0 \mathrm{ml}$; trace minerals $(10 \times) 10 \mathrm{ml}$ (Balch et al., 1979). For large-scale fermentation and subsequent cultivation of the isolate, Bacto peptone and Bacto yeast extract were replaced by $0.3 \mathrm{~g} \mathrm{NH} \mathrm{NH}_{4} \mathrm{Cl}$, and $2.38 \mathrm{~g}$ $\mathrm{CaCl}_{2} .2 \mathrm{H}_{2} \mathrm{O}$; the amount of elemental sulfur was reduced to $0.5 \mathrm{~g} \mathrm{l}^{-1}$. The $\mathrm{pH}$ was adjusted to $7 \cdot 0$ with $\mathrm{H}_{2} \mathrm{SO}_{4}(25 \%)$. The medium was mixed with an UltraTurrax for 1 min, deoxygenated under a stream of $\mathrm{N}_{2}$ for $20 \mathrm{~min}$ and dispensed in $20 \mathrm{ml}$ portions in $120 \mathrm{ml}$ type III borosilicate bottles (Pharmapack; Stute) under a $\mathrm{N}_{2}$ atmosphere. Prior to sterilization for $90 \mathrm{~min}$ at $100^{\circ} \mathrm{C}$, the atmosphere was changed to $\mathrm{H}_{2} / \mathrm{CO}_{2}(80: 20 ; 300 \mathrm{kPa})$. Twenty $\mathrm{ml}$ of air was added to the headspace of the serum bottles by use of a sterile filter after autoclaving the medium. Mass cultures of $\mathrm{VM}^{\mathrm{T}}$ were grown in a 101 titanium fermenter (Braun Biotech). The fermenter was gassed with $120 \mathrm{ml} \mathrm{H}_{2}, 30 \mathrm{ml}$ $\mathrm{CO}_{2}$ and $7.5 \mathrm{ml}$ air $\mathrm{min}^{-1}$. Working with mixtures of hydrogen and oxygen can lead to highly explosive gas mixtures when the hydrogen atmosphere contains more than $25 \%$ air (Aragno \& Schlegel, 1992). Under normal conditions of fermentation, this explosive atmosphere was not formed. To prevent hydrogen entering the room atmospheere, the fermenter was equipped with a direct exhaust pipe out of the building and gas-tight bearings.

In order to analyse carbon source utilization by $\mathrm{VM} 1^{\mathrm{T}}, 3 \mathrm{~g}$ PIPES buffer, adjusted to $\mathrm{pH} 6 \cdot 0$, was added to 11 medium as a buffer and $\mathrm{NaHCO}_{3}$ was omitted from the medium. The carbon sources meat peptone, tryptone, meat extract, yeast extract, lactose, D-galactose, $\alpha$-D-glucose, D-ribose, D-fructose, sucrose, citric acid, $\alpha$-D-maltose hydrate, starch, Dxylose, DL-alanine, L-proline, L-histidine hydrochloride, glycine, methanol, ethanol, acetic acid, pyruvate, disodium fumarate, DL-malate and ammonium formate were added individually at concentrations of $0 \cdot 1 \%$. The gas atmosphere was $99 \% \mathrm{H}_{2}(300 \mathrm{kPa})$ and $1 \% \mathrm{O}_{2}$. To analyse growth of the strain in the presence of organic carbon sources and in the absence of hydrogen, the strain was cultivated under a $\mathrm{N}_{2} / \mathrm{CO}_{2}$ atmosphere $(80: 20 ; 300 \mathrm{kPa})$ in the presence of $1 \%$ $\mathrm{O}_{2}$. Growth on the carbon sources yeast extract, glucose, starch, peptone, tryptone and maltose, added individually at final concentrations of $0 \cdot 1 \%$, was assayed under a hydrogenfree atmosphere.

The gas atmosphere was changed to $\mathrm{N}_{2} / \mathrm{CO}_{2}(80: 20)$ to test for nitrogen fixation and the ability to use thiosulfate and elemental sulfur as electron donators. Oxygen was omitted when testing sulfate and nitrate $\left(0.1 \% \mathrm{KNO}_{3}, \mathrm{w} / \mathrm{v}\right)$ as electron acceptors.

Isolation procedure. Pure cultures were obtained by repeated transfers of serial dilution cultures. The cultures were checked for contamination using a phase-contrast light microscope (Zeiss). The purity of the cultures was confirmed by repeated partial sequence analysis of the gene encoding $16 \mathrm{~S}$ rRNA.

Gram staining. Gram staining was performed by using the Bacto 3-step Gram-stain procedure (Difco).

Measurement of growth. Growth experiments were set up in $120 \mathrm{ml}$ serum bottles that were incubated in a reciprocally shaking water bath (100 r.p.m.). Growth curves were determined by direct counting using a Thoma Blau Brand chamber (Omnilab-Laborzentrum) with a depth of $0.02 \mathrm{~mm}$ under a phase-contrast microscope (Zeiss standard 16). The doubling times were calculated from the slopes of growth curves of three replicates. When the $\mathrm{pH}$ optimum was determined, the $\mathrm{pH}$ was adjusted $1 \mathrm{~d}$ prior to the experiment and readjusted immediately before inoculation using universal pH paper (duotest; Macherey-Nagel).

Electron microscopy. A cell suspension of a well-grown culture was applied to Pioloform-covered 300 mesh Cu grid, washed once with glass-distilled water and sputtered after drying with $\mathrm{Pt} / \mathrm{C}$ at an angle of $40^{\circ}$. A culture was fixed overnight at $4{ }^{\circ} \mathrm{C}$ with $2 \%$ glutaraldehyde and $0.05 \%$ ruthenium red prior to thin sectioning. After centrifugation $(10000 \mathrm{~g}, 10 \mathrm{~min})$, the cells were washed three times in cacodylate buffer $(0 \cdot 1 \mathrm{M}, \mathrm{pH} 7 \cdot 0)$. The pellet was post-fixed for $3 \mathrm{~h}$ at $4{ }^{\circ} \mathrm{C}$ with a mixture of equal volumes of $\mathrm{OsO}_{4}$ 
$(2 \%)$, ruthenium red $(0 \cdot 15 \%)$ and cacodylate buffer $(0 \cdot 2 \mathrm{M})$. It was dehydrated in ascending concentrations of ethanol using propylene oxide as the intermediate medium and embedded in Spurr's resin. Ultrathin sections were cut using a Reichert-Ultracut S ultramicrotome. Sections were stained with uranyl acetate and lead citrate (Reynolds, 1963). Electron micrographs were taken using a Philips EM 300 electron microscope at $80 \mathrm{kV}$ on Kodak electron microscope film (no. 4489).

Extraction of respiratory lipoquinones and polar lipids. Respiratory lipoquinones and polar lipids were extracted from $100 \mathrm{mg}$ freeze-dried cell material using the two-stage method described by Tindall (1990a, b). Respiratory quinones were extracted using methanol/hexane (Tindall, $1990 \mathrm{a}, \mathrm{b})$ and the polar lipids were extracted by adjusting the remaining methanol $/ 0 \cdot 3 \%$ aqueous $\mathrm{NaCl}$ phase (containing the cell debris) to give a choroform $/$ methanol $/ 0.3 \%$ aqueous $\mathrm{NaCl}$ mixture $(1: 2: 0 \cdot 8$, by vol.). The extraction solvent was stirred overnight and the cell debris was pelleted by centrifugation. Polar lipids were recovered into the chloroform phase by adjusting the chloroform $/$ methanol $/ 0 \cdot 3 \%$ aqueous $\mathrm{NaCl}$ mixture to a ratio of $1: 1: 0 \cdot 9$ (by vol.).

Analysis of respiratory lipoquinones. Respiratory lipoquinones were separated into their different classes (e.g. menaquinones and ubiquinones) by TLC on silica gel (Macherey-Nagel art. no. 805023), using hexane/tert-butyl methyl ether $(9: 1, \mathrm{v} / \mathrm{v})$ as solvent. UV-absorbing bands corresponding to respiratory quinones were removed from the plate and analysed further by HPLC. This step was carried out on an LDC Analytical HPLC (Thermo Separation Products) fitted with a reverse-phase column $\left(2 \times 125 \mathrm{~mm}, \quad 3 \mu \mathrm{m}, \quad \mathrm{RP} \backslash_{18} ; \quad\right.$ Macherey-Nagel $)$ using methanol/heptane $(10: 2, \mathrm{v} / \mathrm{v})$ as the eluant. Respiratory lipoquinones were detected at $269 \mathrm{~nm}$.

Analysis of polar lipids. Polar lipids were separated by twodimensional silica-gel TLC (Macherey-Nagel art. no. $818135)$. The first direction was developed in chloroform/ methanol/water $(65: 25: 4$, by vol.) and the second in chloroform/methanol/acetic acid/water $(80: 12: 15: 4$, by vol.). Total lipid material and specific functional groups were detected using dodecamolybdophosphoric acid (total lipids), Zinzadze reagent (phosphate), ninhydrin (free amino groups), periodate-Schiff ( $\alpha$-glycols), Dragendorff reagent (quaternary nitrogen) and anisaldehyde/sulfuric acid (glycolipids).

Analyses of fatty acids. Fatty acids were analysed as the methyl ester derivatives prepared from $30 \mathrm{mg}$ frozen cell material. Fatty acid methyl esters were analysed by gas chromatography using a $0 \cdot 2 \mu \mathrm{m} \times 25 \mathrm{~m}$ non-polar capillary column and flame ionization detection. The run conditions were: injection and detector port temperature, $250{ }^{\circ} \mathrm{C}$; inlet pressure, 9 p.s.i. (62 $\mathrm{kPa})$; split ratio, $50: 1$; injection volume, $2 \mu \mathrm{l}$; with a temperature program from 170 to $310^{\circ} \mathrm{C}$ at a rate of $7^{\circ} \mathrm{C} \mathrm{min}^{-1}$.

Analysis for the presence of compounds in addition to fatty acids. The presence of fatty acids and other compounds (i.e. mono- and diethers or long chain diols) was analysed following hydrolysis of $10 \mathrm{mg}$ dry cell material. Cell material from Thermodesulfobacterium commune (kindly supplied by T. A. Langworthy) served as reference material for the presence of non-isoprenoid mono- and diethers. Cell material was incubated for $18 \mathrm{~h}$ at $50{ }^{\circ} \mathrm{C}$ in $11 \mathrm{methanol} /$ tert butyl methyl ether/sulfuric acid $(5: 5: 0 \cdot 2$ by vol.). Fatty acid methyl esters and other components released from the lipids were recovered by cooling the hydrolysis mixture to room temperature and adding $0.5 \mathrm{ml} 10 \% \mathrm{NH}_{4} \mathrm{HCO}_{3}$ to neutralize the acid. This also caused the tert-butyl methyl ether phase to separate from the lower, aqueous methanol phase and allowed recovery of the hydrolysed lipophilic material. Fivehundred microlitres tert-butyl methyl ether was added to the aqueous methanol phase, the suspension was shaken and the upper, tert-butyl methyl ether phase was pooled with the first tert-butyl methyl ether layer. Fatty acids, diethers and monoethers were separated on silica-gel thin layers using hexane/diethyl ether/acetic acid (25:25:1, by vol.) as the solvent system. Lipid material was visualized using $5 \%$ ethanolic dodecamolybdophosphoric acid after heating to $150{ }^{\circ} \mathrm{C}$ for $30 \mathrm{~min}$. The presence of vicinal hydroxyl groups was detected using the periodate-Schiff reagent.

DNA base composition. The DNA $\mathrm{G}+\mathrm{C}$ content was determined by HPLC according to Mesbah et al. (1989). Non-methylated lambda DNA (Sigma) was used as a standard.

DNA isolation. About $5 \mathrm{mg}$ lyophilized cells (a tip of a spatula) was resuspended in $150 \mu 1$ sterile distilled water. A preincubation of $10 \mathrm{~min}$ at $37^{\circ} \mathrm{C}$ was followed by the addition of $567 \mu \mathrm{l}$ Tris/EDTA buffer (10 mM, pH 8.0), $30 \mu \mathrm{l}$ $10 \%$ SDS and $3 \mu \mathrm{l}$ proteinase $\mathrm{K}\left(20 \mathrm{mg} \mathrm{ml}^{-1}\right.$; Sigma $)$. After incubation for $1 \mathrm{~h}$ at $37^{\circ} \mathrm{C}, 100 \mu \mathrm{NaCl}$ and $80 \mu \mathrm{l} 10 \%$ CTAB were added and the mixture was incubated at $65^{\circ} \mathrm{C}$ for $30 \mathrm{~min}$. DNA was extracted by treatment with phenol/ chloroform $(1: 1)$ and twice with chloroform. It was precipitated with 2-propanol, washed with ethanol $(70 \%)$ and dissolved in $10 \mu \mathrm{l}$ sterile distilled water.

Phylogenetic analysis. The $16 \mathrm{~S}$ rRNA gene was amplified from isolated DNA by PCR. PCRs contained: $5.0 \mu \mathrm{l}$ RP buffer [1 M Tris/HCl, pH 9.0, $400 \mathrm{mM}\left(\mathrm{NH}_{4}\right)_{2} \mathrm{SO}_{4}, 30 \mathrm{mM}$ $\mathrm{MgCl}_{2}$ ], $10 \mu \mathrm{l}$ dNTP mix $(2 \cdot 5 \mathrm{mM}$ each of dATP, dCTP, dGTP and dTTP), $2 \mu 112 \cdot 5 \mu \mathrm{M}$ forward primer (5'-GAGTTTGATCCTGGCTCAG-3', positions 9-27), $2 \mu 1$ $12.5 \mu \mathrm{M}$ reverse primer (5'-TACGGCTACCTTGTTACGACTT-3', positions 1510-1492; Pharmacia), 0.5 $\mu$ l DNA template $(10-100 \mathrm{ng}), 80 \mu \mathrm{l}$ sterile distilled water and $50 \mu \mathrm{l}$ mineral oil. Taq DNA polymerase $(2.5 \mathrm{U}$; Boehringer Mannheim) was added after a 'hot start'. PCR was performed in a Mastercycler (Eppendorf) using the following program: $4 \mathrm{~min}$ at $94^{\circ} \mathrm{C}, 72^{\circ} \mathrm{C}$ during addition of the enzyme and 35 cycles of $45 \mathrm{~s}$ at $94{ }^{\circ} \mathrm{C}, 45 \mathrm{~s}$ at $50^{\circ} \mathrm{C}$ and $75 \mathrm{~s}$ at $72^{\circ} \mathrm{C}$. After 35 cycles, extension was continued for 10 min at $72{ }^{\circ} \mathrm{C}$ and the cycler was cooled to $4{ }^{\circ} \mathrm{C}$.

The PCR product was purified using the Wizard PCR Prep DNA purification system (Promega) and collected in $100 \mu 1$ double-distilled water. The concentration of DNA was estimated from an agarose gel stained with ethidium bromide. The sequence of the PCR product was determined using the AmpliCycle TM sequencing kit (Perkin Elmer). $\left[{ }^{35} \mathrm{~S}\right] \mathrm{ATP} \gamma \mathrm{S}$ was used for labelling. The $16 \mathrm{~S}$ rRNA gene sequences of the new isolates were aligned using CLUSTAL W version 1.7 (Thompson et al., 1994) with sequences taken from the Ribosomal Database Project (RDP) (Olsen et al., 1991) and EMBL database. Programs of the PHYLIP package (version 3.5) (Felsenstein, 1989) were used for calculations. Distance matrixes were set up using DNADIST with the Jukes-Cantor (Jukes \& Cantor, 1969) and maximumlikelihood option. The neighbour-joining method and the FITCH program generated tree estimations with a random order input and a global rearrangement option activated. Bootstrap analysis with 1000 replicates was performed using the SEQBOOT and CONSENSE programs of the same package. 


\section{RESULTS}

\section{Enrichment and isolation}

In searching for marine, thermophilic, hydrogenoxidizing bacteria, water-plus-sediment samples were collected from a shallow hydrothermal area of Vulcano Island, Italy. The enrichment culture was set up using $20 \mathrm{ml}$ modified marine medium inoculated with $1 \mathrm{ml}$ samples and a gas atmosphere of $\mathrm{H}_{2} / \mathrm{CO}_{2} / \mathrm{O}_{2}(80: 20$ : $1 \cdot 2)$ pressurized to 2 bars $(200 \mathrm{kPa})$. After incubation for $1 \mathrm{~d}$ at $75^{\circ} \mathrm{C}$, the culture became turbid. A series of serial dilutions led to the isolation of $\mathrm{VM} 1^{\mathrm{T}}$. Purity of the culture was checked microscopically and by sequence analysis of $16 \mathrm{~S}$ rRNA.

\section{Morphological characteristics}

Cells of $\mathrm{VM}^{\mathrm{T}}$ were rods that were Gram-negative. The cells were $2-4 \mu \mathrm{m}$ long and $1-1.5 \mu \mathrm{m}$ wide. Microscope examination revealed that they were motile at room temperature. Formation of endospores was not observed. Electron microscopy showed that cells contained four to seven monopolar flagella (Fig. 1a). Analysis of ultrathin sections revealed a cell wall structure typical of Gram-negative bacteria (Fig. 1b).

\section{Physiological characterization}

Strain VM1 $1^{\mathrm{T}}$ was isolated at $75^{\circ} \mathrm{C}$. Optimal growth was observed at $65^{\circ} \mathrm{C}$, whereas no growth occurred at 35 or $85^{\circ} \mathrm{C}$ (Fig. 2a). The strain grew at $\mathrm{NaCl}$ concentrations in the range $0.5-6 \%$. Optimal growth occurred at 2 and $3 \%$ (Fig. 2b). Thermophilic, hydrogen-oxidizing bacteria are especially sensitive to high oxygen concentrations; $\mathrm{VM} 1^{\mathrm{T}}$ tolerated $\mathrm{O}_{2}$ up to $8 \%$, although optimal growth was observed at $1-2 \%$ $\mathrm{O}_{2}$ in the atmosphere (Fig. 2c). Growth occurred over a range of $\mathrm{pH}$ between 5 and 7 (data not shown).

\section{Carbon source utilization and other nutritional features}

Strain VM $1^{\mathrm{T}}$ showed good growth under lithotrophic conditions with $\mathrm{H}_{2}$ as electron donor, $\mathrm{O}_{2}$ as electron acceptor and $\mathrm{CO}_{2}$ as the source of carbon. Therefore, the complex components of the modified marine medium in which strain $\mathrm{VM}^{\mathrm{T}}$ was isolated were replaced by $\mathrm{NH}_{4} \mathrm{Cl}$ as a source of cellular nitrogen.

In order to test whether the strain could use organic substances as sole carbon sources, the gas atmosphere was changed to $\mathrm{H}_{2} / \mathrm{O}_{2}(99: 1)$ with a variety of organic carbon sources added $(0 \cdot 1 \%)$. None of these 25 organic compounds were utilized, which was taken as an indication of obligately autotrophic growth. In order to test whether organic substances could replace hydrogen as a source of energy, growth in the presence of yeast extract, peptone, tryptone, starch, glucose and maltose was assayed under a $\mathrm{N}_{2} / \mathrm{CO}_{2}$ atmosphere (80:
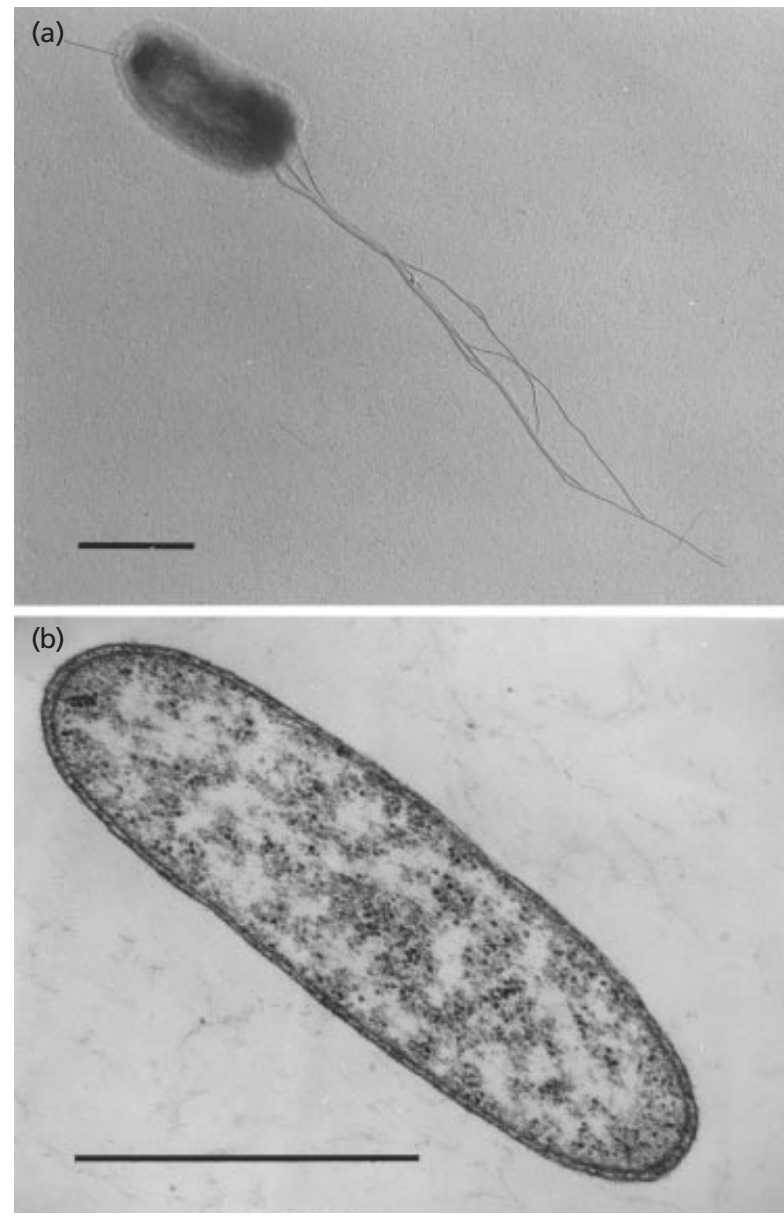

Fig. 1. Electron micrograph of an ice-dried, platinum-shadowed cell with flagella (a) and a thin section of a cell (b) of isolate VM1 $1^{\top}$. Bars, $1.0 \mu \mathrm{m}$.

$20 ; 300 \mathrm{kPa}$ ) containing $1 \%$ oxygen in addition. The strain did not grow under these conditions. This finding indicates that hydrogen cannot be replaced as the electron donor by these organic substances. Some thermophilic, hydrogen-oxidizing organisms can use elemental sulfur or thiosulfate as alternate electron donors. Growth of $\mathrm{VM} 1^{\mathrm{T}}$ was dependent on elemental sulfur in the medium, but it could not grow in the presence of sulfur or thiosulfate under a $\mathrm{N}_{2} / \mathrm{CO}_{2}$ atmosphere $(80: 20 ; 300 \mathrm{kPa})$ containing $1 \%$ oxygen in addition. This finding suggests that sulfur is required as a source for the biosynthesis of cellular sulfurcontaining compounds, but cannot be used as the sole electron donor.

Oxygen was omitted from the gas atmosphere and was replaced by $\mathrm{KNO}_{3}(0 \cdot 1 \%)$ in the medium to test whether nitrate was a suitable electron acceptor. The strain was not capable of using either nitrate or sulfate as electron acceptors. In the presence of $\mathrm{O}_{2}$, nitrate was tested as a source of cellular nitrogen, but there was no growth. 

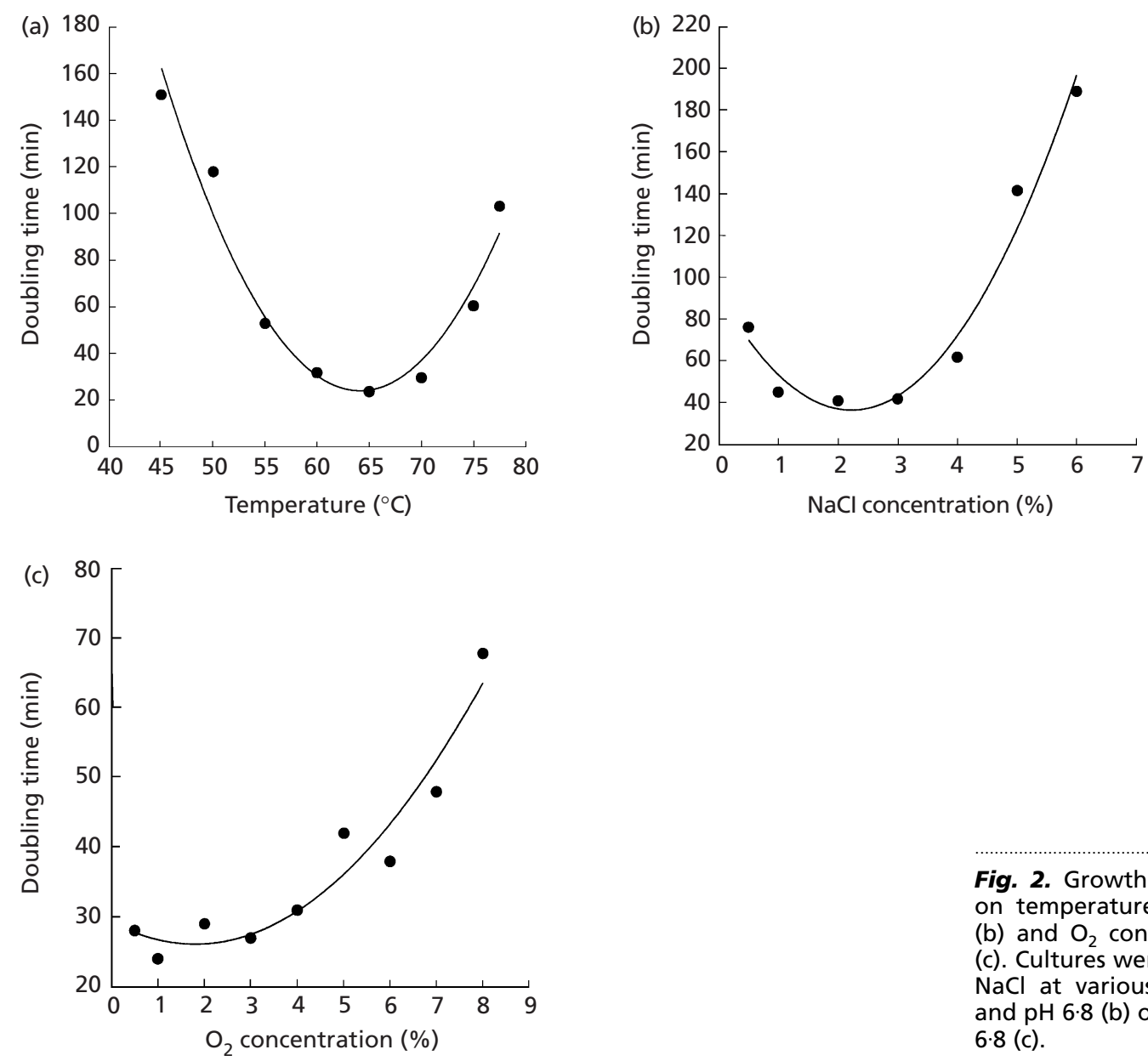

Fig. 2. Growth of isolate $\mathrm{VM} 1^{\top}$ dependent on temperature (a), concentration of $\mathrm{NaCl}$ (b) and $\mathrm{O}_{2}$ concentration in the headspace (c). Cultures were grown at $\mathrm{pH} 6.8$ and $1.9 \%$ $\mathrm{NaCl}$ at various temperatures (a), at $65^{\circ} \mathrm{C}$ and $\mathrm{pH} 6.8$ (b) or at $65^{\circ} \mathrm{C}, 1.9 \% \mathrm{NaCl}$ and $\mathrm{pH}$ $6 \cdot 8$ (c).

Table 1. Major components of the fatty acids of representatives of the phylum 'Hydrogenobacter/Aquifex'

Values are percentages of total fatty acids unless otherwise indicated. +++ , Major component, not quantified; - , not detected. Data for Hydrogenobacter thermophilus and 'Hydrogenobacter halophilus' were taken from Kawasumi et al. (1984) and Nishihara et al. (1990), respectively.

\begin{tabular}{|c|c|c|c|c|c|}
\hline Fatty acid & $\begin{array}{l}\text { Hydrogenobacter } \\
\text { thermophilus }\end{array}$ & $\begin{array}{c}\text { 'Hydrogenobacter } \\
\text { halophilus' }\end{array}$ & $\begin{array}{c}\text { Hydrogenobaculum } \\
\text { acidophilum }\end{array}$ & $\begin{array}{c}\text { Aquifex } \\
\text { pyrophilus }\end{array}$ & $\begin{array}{l}\text { Hydrogenothermus } \\
\text { marinus } \mathrm{VM1}^{\mathrm{T}}\end{array}$ \\
\hline$C_{18: 0}$ & +++ & 15 & $23-28$ & $22-25$ & $22-24$ \\
\hline $\mathrm{C}_{18: 1} \omega 9 c$ & - & 19 & $16-29$ & $4-7$ & $15-16$ \\
\hline $\mathrm{C}_{20: 1} \omega 9 c$ & $+++^{*}$ & $43-44$ & $37-43$ & $22-28$ & $46-51$ \\
\hline $\mathrm{X}\left(R_{\mathrm{f}} 0 \cdot 086\right)$ & - & - & - & $16-27$ & - \\
\hline
\end{tabular}

* Position of the double bond not specified in the literature.

$\mathrm{VM} 1^{\mathrm{T}}$ was both catalase- and cytochrome-oxidasepositive.

\section{Analysis of fatty acids and respiratory quinones}

Fatty acids were analysed as methyl ester derivates prepared from $30 \mathrm{mg}$ frozen cell material. Analysis of the major fatty acids of $\mathrm{VM} 1^{\mathrm{T}}$, Hydrogenobacter thermophilus and Hydrogenobacter acidophilus revealed straight-chain saturated $\mathrm{C}_{18: 0}$ and unsatu- rated $\mathrm{C}_{18: 1} \omega 9 c$ and $\mathrm{C}_{20: 1} \omega 9 c$ as major components. In contrast, Aquifex pyrophilus lacked $\mathrm{C}_{18: 1} \omega 9 c$ as a major component but instead had another component, $\mathrm{X}\left(R_{\mathrm{f}}=0.086\right)($ Table 1$)$.

Analysis of the quinone compounds revealed one major and one minor compound to be present, neither of which co-chromatographed with the two compounds present in Hydrogenobacter acidophilus, indicating that they were novel compounds. Examination 


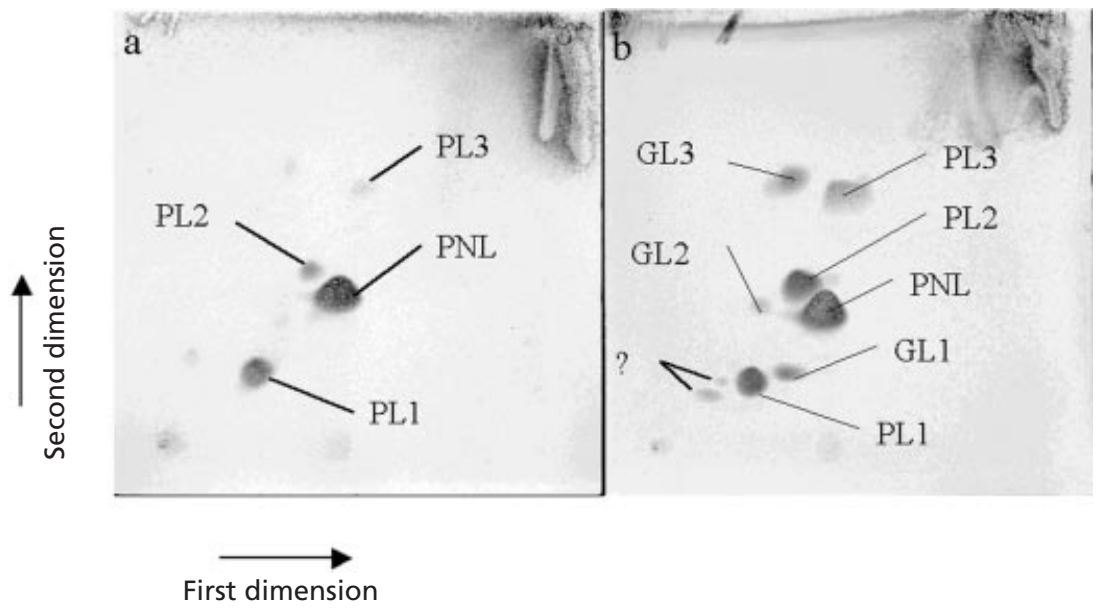

Fig. 3. Two-dimensional chromatographic separation of polar lipids of Hydrogenobacter acidophilus (a) and $\mathrm{VM}^{\top}$ (b). PL, Phospholipid; PNL, aminophospholipid; GL, glycolipid.

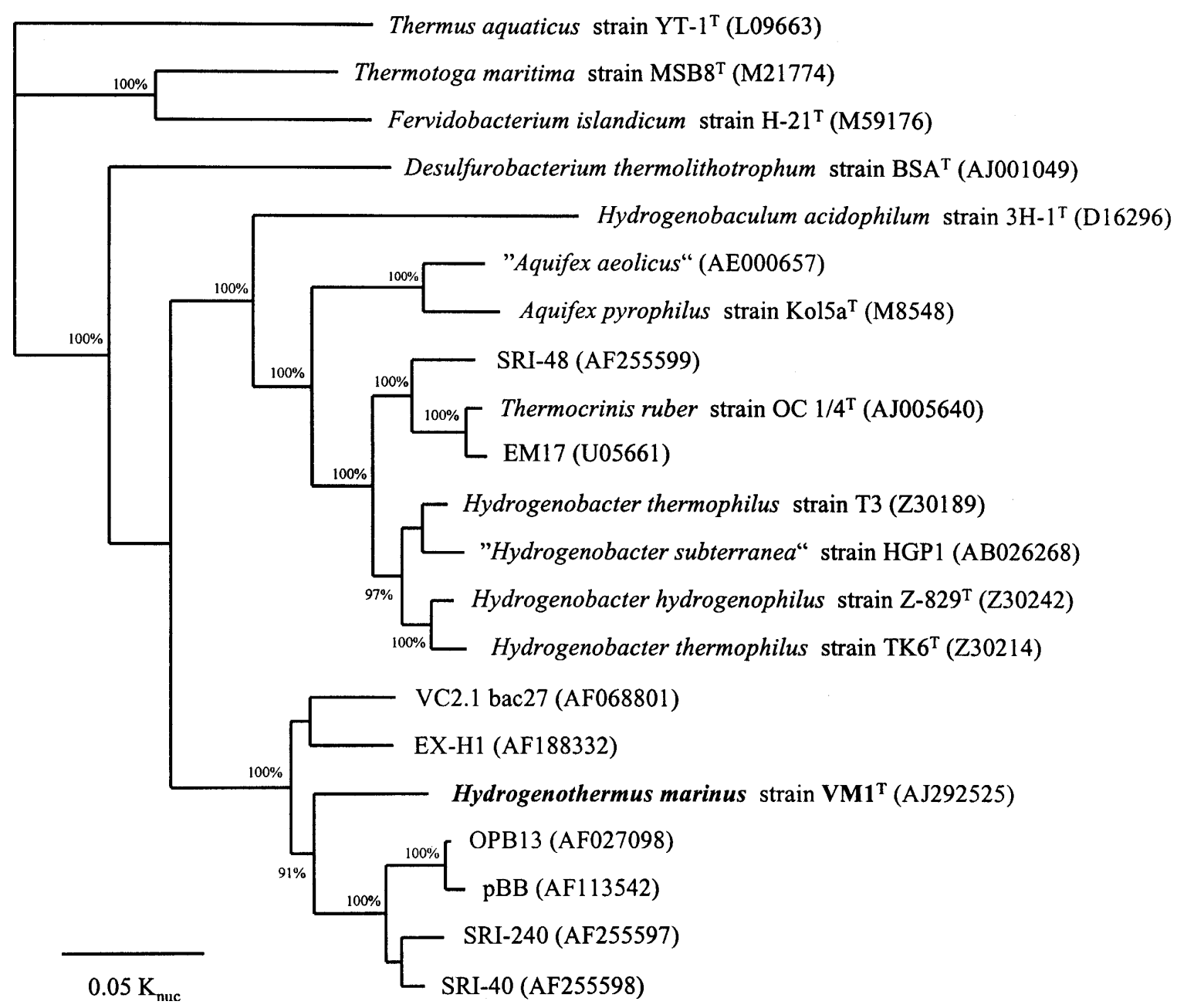

Fig. 4. Phylogenetic dendrogram based on $16 \mathrm{~S}$ rDNA sequences showing the relationship of the novel isolate $\mathrm{VM} 1^{\top}$ to the members of the phylum 'Hydrogenobacter/Aquifex'. Confidence limits expressed as percentages were determined by bootstrap analysis with 1000 replicates. Only confidence limits of more than $95 \%$ are shown.

of the mass spectrum of the major compound indicated that it produced a fragment at $m / z=257$, characteristic of the menathioquinone ring nucleus (Ishii et al., 1983, 1987), MTK-7H 4 serving as an authentic reference. The molecular ion was shifted by 4 mass units compared with MTK- $7 \mathrm{H}_{4}$, giving a molecular ion at $m / z=680$. This would suggest that the compound also contains a heptaprenyl side chain, but that 
none of the double bonds are hydrogenated. Further work is in progress for a complete characterization of the new compound but, on the basis of evidence collected to date, we infer that the major compound is probably a menathioquinone with a heptaprenyl side chain (i.e. MTK-7).

\section{Analysis of polar lipids}

The polar lipid compositions of strain $\mathrm{VM}^{\mathrm{T}}$ and Hydrogenobacter acidophilus were compared. Both strains were dominated by the presence of phospholipids. Strain $\mathrm{VM} 1^{\mathrm{T}}$ also contained small amounts of glycolipids. The major phospholipids present in all strains were an aminophospholipid (PNL) and a phospholipid (PL1). These results are also consistent with the report of similar compounds in Aquifex pyrophilus (Huber et al., 1992). PNL did not, however, have an $R_{\mathrm{f}}$ value similar to that of authentic phosphatidylethanolamine and we have therefore refrained from assigning this structure to this compound. The polar lipid composition of the strains examined differed and allowed them to be distinguished easily on this basis (Fig. 3). No data are currently available for Hydrogenobacter thermophilus, Thermocrinis ruber or Calderobacterium hydrogenophilum.

\section{DNA base composition}

The mean DNA base composition was determined by HPLC (Mesbah et al., 1989). The $\mathrm{G}+\mathrm{C}$ content of strain $\mathrm{VM}^{\mathrm{T}}$ was $43 \cdot 0 \mathrm{~mol} \%$.

\section{Phylogeny}

A sequence of 1433 bases of the $16 \mathrm{~S}$ rRNA of VM1 ${ }^{\mathrm{T}}$ was determined. Phylogenetic analysis using the Jukes $\&$ Cantor equation for distance-matrix calculation and the program FITCH for calculation of a phylogenetic tree placed the strain in the same phylum as members of the genera Aquifex and Hydrogenobacter (Fig. 4). Within this group, the strain represents a new, deepbranching lineage with respective sequence similarities of 85.9 and $87.6 \%$ to Hydrogenobacter acidophilus and Aquifex pyrophilus. A similar topology was also found using the maximum-likelihood option to calculate the distance matrix and the neighbour-joining method to calculate the phylogenetic tree. The significance of the topology was tested further by bootstrap analysis using 1000 replicates.

Although we included Hydrogenobacter thermophilus strain T3 and 'Hydrogenobacter subterranea', no information on the latter organism was found in the literature.

\section{DISCUSSION}

Isolate $\mathrm{VM} 1^{\mathrm{T}}$, from a shallow marine hydrothermal area of Vulcano Island, Italy, was placed within the phylum of hyperthermophilic and thermophilic hydrogen-oxidizers by $16 \mathrm{~S}$ rDNA analysis. This phylum includes the genera Aquifex, Hydrogenobacter, Calderobacterium and Thermocrinis, which all include Gram-negative bacteria with a chemolithoautotrophic metabolism. Growth above $70^{\circ} \mathrm{C}$ currently distinguishes this group from other thermophilic, Gramnegative, hydrogen-oxidizing bacteria such as ' Pseudomonas thermophila' and Flavobacterium thermophilum (Aragno \& Schlegel, 1992), Hydrogenophilus thermoluteolus (Hayashi et al., 1999) and Hydrogenophilus hirschii (Stöhr et al., 2001). The latter two belong to the $\beta$-subclass of the Proteobacteria and grow below $70{ }^{\circ} \mathrm{C}$ with a range between 50 and $68{ }^{\circ} \mathrm{C}$.

The new isolate, $\mathrm{VM} 1^{\mathrm{T}}$, exhibits, together with Hydrogenobacter acidophilus, a lower temperature optimum of $65^{\circ} \mathrm{C}$. As an isolate of marine origin, $\mathrm{VM} 1^{\mathrm{T}}$ can clearly be separated from most Hydrogenobacter strains, which cannot tolerate $\mathrm{NaCl}$ concentrations of $0.3 \mathrm{M}(1.74 \%)$ or more (Nishihara et al., 1990; Kristjansson et al., 1985). The only exception to date is 'Hydrogenobacter halophilus', which grows optimally between 0.3 and $0.5 \mathrm{M} \mathrm{NaCl}$ (Nishihara et al., 1990). However, at the time of writing, this organism was not available. 'Hydrogenobacter halophilus' did not grow in $1 \mathrm{M} \mathrm{NaCl}$, whereas $\mathrm{VM}^{\mathrm{T}}$ tolerates $6 \%(1.03 \mathrm{M})$ $\mathrm{NaCl}$. In contrast to 'Hydrogenobacter halophilus', strain $\mathrm{VM} 1^{\mathrm{T}}$ is motile by means of four to seven flagella. In contrast to all hitherto-described representatives of the genera Hydrogenobacter, Aquifex and Thermocrinis (Bonjour \& Aragno, 1986; Huber et al., 1992; Shima \& Suzuki, 1993; Huber et al., 1998), this organism cannot use sulfur or thiosulfate as alternate electron donors. $\mathrm{VM} 1^{\mathrm{T}}$ is the only organism of this bacterial phylum whose growth is strictly dependent upon the presence of hydrogen as an electron donor. Like Hydrogenbacter acidophilus, it requires elemental sulfur for growth. In contrast to Aquifex pyrophilus, nitrate could not substitute for oxygen as an electron acceptor. A comparison of the fatty acid composition revealed that $\mathrm{C}_{18: 0}, \mathrm{C}_{18: 1}$ and $\mathrm{C}_{20: 1}$ are characteristic for Hydrogenobacter thermophilus, Hydrogenobacter acidophilus, 'Hydrogenobacter halophilus' (Nishihara et al., 1990) and isolate $\mathrm{VM}^{\mathrm{T}}$ (Table 1). Aquifex pyrophilus can be distinguished from this group because it only possesses low levels of $\mathrm{C}_{18: 1} \omega 9 c$. An additional, uncharacterized, major component is found instead (Table 1). Mono- and diethers found in Aquifex pyrophilus (Huber et al., 1992) could not be detected in strain $\mathrm{VM} 1^{\mathrm{T}}$.

The major compound of the quinone systems of Hydrogenobacter thermophilus and Hydrogenobacter halophilus is 2-methylthio-3-VI,VII-tetrahydroheptaprenyl-1,4-naphthoquinone. In $\mathrm{VM}^{\mathrm{T}}$, one major and one minor compound were present, neither of which co-chromatographed with the compounds present in Hydrogenobacter acidophilus. Instead, $\mathrm{VM}^{\mathrm{T}}$ appears to contain a novel menathioquinone, the structure of which is currently not known. 
Taken together, these findings indicate that $\mathrm{VM}^{\mathrm{T}}$ represents a new genus, for which we propose the name Hydrogenothermus gen. nov., with the type species Hydrogenothermus marinus sp. nov.

Sequences of several uncultivated bacterial rDNA clones related to the phylum 'Hydrogenobacter/Aquifex' have been published or deposited in the EMBL database that originate from hydrothermal environments and one thermophilic, hydrogen-oxidizing isolate, EX-H1, has been reported (Reysenbach et al., 1994, 2000). We have included the clones whose 16S rDNA sequence had been determined up to a length of at least 1433 nucleotides in our phylogenetic analyses. The environmental DNAs EM17 and SRI-48 were closely related to Thermocrinis ruber. Most other environmental clones, VC2.1 bac27, OPB13, pBB, SRI-240, SRI-40 and the isolate EX-H1, clustered together with $\mathrm{VM}^{\mathrm{T}}$ (Fig. 4). These findings suggest a high diversity of the novel taxon described here. Furthermore, relatives of $\mathrm{VM} 1^{\mathrm{T}}$ that might represent additional genera and species seem to be distributed widely in geothermally heated habitats.

In addition to the description of a new species of thermophilic hydrogen oxidizer, we also included in the $16 \mathrm{~S}$ rDNA analysis all members of the genera Hydrogenobacter, Aquifex, Calderobacterium and Thermocrinis, the names of which have been validly published (Fig. 4). In addition to showing that Hydrogenobacter acidophilus is related only distantly to Hydrogenobacter thermophilus, our results also show that Thermocrinis ruber and Calderobacterium hydrogenophilum are closely related to Hydrogenobacter thermophilus. While Thermocrinis ruber differs in some respect from Hydrogenobacter thermophilus, and this still justifies its inclusion in a separate genus, the close relationship between the type strains of Hydrogenobacter thermophilus and Calderobacterium hydrogenophilum indicates that the latter species may be considered to be either a strain of the species Hydrogenobacter thermophilus or a distinct species within the genus Hydrogenobacter. Shima \& Suzuki (1993) have presented DNA-DNA hybridization data that indicate that the type strains of the species Hydrogenobacter thermophilus and Calderobacterium hydrogenophilum are not members of the same species, despite their high degree of $16 \mathrm{~S}$ rDNA sequence similarity. Consequently, we propose that Calderobacterium hydrogenophilum should be transferred to the genus Hydrogenobacter as a new combination, Hydrogenobacter hydrogenophilus comb. nov.

In addition, $16 \mathrm{~S}$ rDNA sequence analyses indicate that Hydrogenobacter acidophilus belongs to a lineage that is distant from the Hydrogenobacter and Aquifex cluster (Fig. 4). Furthermore, this strain can be distinguished phenotypically from all these strains by its low $\mathrm{pH}$ optimum for growth, $\mathrm{pH}$ 3-4 (Shima \& Suzuki, 1993). We therefore propose to classify this organism in a new genus as Hydrogenobaculum acidophilum gen. nov., comb. nov.

\section{Description of Hydrogenobacter hydrogenophilus (Kryukov et al. 1984) comb. nov.}

Basonym: Calderobacterium hydrogenophilum.

The species description is identical to that given by Kyrukov et al. (1983). The type strain is strain INMI $\mathrm{Z}-829^{\mathrm{T}}\left(=\mathrm{DSM} 2913^{\mathrm{T}}=\mathrm{JCM} 8158^{\mathrm{T}}\right)$.

\section{Description of Hydrogenobaculum (ex Shima and Suzuki 1993) gen. nov.}

Hydrogenobaculum (Hy.dro.ge.no.ba'cu.lum. Gr. n. hydor water; Gr. v. genein to produce; L. neut. n. baculum small rod; N.L. neut. n. Hydrogenobaculum water-producing small rod).

Gram-negative, non-sporulating rods. Motile. Respiratory metabolism; molecular oxygen is used as the electron acceptor, hydrogen and reduced sulfur compounds as electron donors and carbon dioxide as a carbon source. Carbon dioxide is fixed via the reductive tricarboxylic acid cycle. Requires elemental sulfur or thiosulfate for growth. The optimum $\mathrm{pH}$ for growth is 3-4. 2-Methylthio-3-VI,VII-tetrahydromultiprenyl ${ }^{7}-1,4$-naphthoquinone (methionaquinone) is the major component of the quinone system. The type species is Hydrogenobaculum acidophilum. The similarity of the sequence of $16 \mathrm{~S}$ rDNA of Hydrogenobaculum acidophilum is around $86 \%$ to that of Hydrogenothermus marinus and $88 \%$ to that of Aquifex pyrophilus.

\section{Description of Hydrogenobaculum acidophilum (Shima and Suzuki 1993) comb. nov.}

\section{Basonym: Hydrogenobacter acidophilus.}

Cells are short rods $(0.4-0.6 \times 1.3-1.8 \mu \mathrm{m})$ that occur singly or in linked chains containing two to four cells. Polar flagellation. Hydrogenases are membranebound and soluble. The soluble hydrogenases do not reduce pyrimidine nucleotides. Type $b, c$ and $o$ cytochromes are found. The optimum temperature for growth is $65^{\circ} \mathrm{C}$. The $\mathrm{G}+\mathrm{C}$ content of the DNA is 35 mol \% (as determined by HPLC). Straight-chain saturated $\mathrm{C}_{18: 0}$ and straight-chain unsaturated $\mathrm{C}_{18: 1}$ and $\mathrm{C}_{20: 1}$ acids are the major components of the cellular fatty acids.

Isolated from mud samples from a solfataric field in Tsumagoi, Japan. The type strain is strain $3 \mathrm{H}-1^{\mathrm{T}}$ $\left(=\mathrm{JCM} 8795^{\mathrm{T}}=\right.$ DSM $\left.11251^{\mathrm{T}}\right)$.

\section{Description of Hydrogenothermus gen. nov.}

Hydrogenothermus (Hy.dro.ge.no.ther'mus. Gr. n. hydor water; Gr. v. genein to produce; Gr. adj. thermos hot; N.L. masc. n. Hydrogenothermus hot and water producer).

Cells are Gram-negative rods that occur singly, in pairs and in aggregates. Cells are motile by polarly inserted flagella. No spore formation. Respiratory metabolism with oxygen as electron acceptor. Chemo- 
lithoautotrophic with hydrogen as electron donor and $\mathrm{CO}_{2}$ as source of cellular carbon. Elemental sulfur and thiosulfate are not utilized as electron donors. No growth factors are required. Chemo-organotrophic growth is not found. Temperature optimum about $65^{\circ} \mathrm{C}$. The major quinone is a menathioquinone, probably with a heptaprenyl side chain (i.e. MTK-7). Acyl mono- and diethers are not present. The predominant fatty acids present are $\mathrm{C}_{18: 0}, \mathrm{C}_{18: 1} \omega 9 c$ and $\mathrm{C}_{20: 1} \omega 9 \mathrm{c}$. The polar lipids comprise phospholipids, a single aminophospholipid and glycolipids. The type species is Hydrogenothermus marinus sp. nov.

\section{Description of Hydrogenothermus marinus sp. nov.}

Hydrogenothermus marinus (ma.ri'nus. L. adj. marinus of marine origin).

Cells are motile, Gram-negative rods, $2-4 \mu \mathrm{m}$ long and $1-1.5 \mu \mathrm{m}$ wide, with four to seven flagella inserted. The strain grows chemolithoautotrophically under an atmosphere of $\mathrm{H}_{2}$ and $\mathrm{CO}_{2}(80: 20)$ with low concentrations of $\mathrm{O}_{2}(0.5-8 \%$, optimum at $1-2 \%)$. No growth on meat peptone, tryptone, meat extract, yeast extract, lactose, D-galactose, $\alpha$-D-glucose, D-ribose, Dfructose, sucrose, citric acid, $\alpha$-D-maltose hydrate, starch, D-xylose, DL-alanine, L-proline, L-histidine hydrochloride, glycine, methanol, ethanol, acetic acid, pyruvate, disodium fumarate, DL-malate or ammonium formate as a source of energy or cellular carbon. Catalase- and cytochrome-oxidase-positive. No growth on peptone, yeast extract, tryptone, starch, glucose or maltose as sole electron donor. Sulfur and thiosulfate are not utilized as electron donors or sources of energy. Elemental sulfur is necessary for growth. Nitrate and sulfate cannot serve as electron acceptors. Growth occurs over the range 45 to $80^{\circ} \mathrm{C}$ with an optimum at $65^{\circ} \mathrm{C}$ at $\mathrm{pH} 5-7 . \mathrm{NaCl}$ stimulates growth between 0.5 and $6 \%$, with an optimum at $2-3 \%$. Isolated from sediment of a geothermally heated area, 3-4 m off the beach of Vulcano, Italy. The type strain is strain $\mathrm{VM} 1^{\mathrm{T}}\left(=\mathrm{DSM} 12046^{\mathrm{T}}=\mathrm{JCM}\right.$ $\left.10974^{\mathrm{T}}\right)$.

\section{ACKNOWLEDGEMENTS}

This paper is dedicated to Professor Karl-Otto Stetter on the occasion of his 60th birthday.

This work was supported in part by the Fonds der Chemischen Industrie. We would like to thank T. A. Langworthy for cell material of Thermodesulfobacterium commune as reference material for the presence of nonisoprenoid mono- and diethers, Hans Trüper for valuable advice and Uta Wehmeyer for technical assistance.

\section{REFERENCES}

Aragno, M. \& Schlegel, H. G. (1992). The mesophilic hydrogen oxidizing (Knallgas) bacteria. In The Prokaryotes, 2 nd edn, pp. 3917-3933. Edited by A. Balows, H. G. Trüper, M. Dworkin, W. Harder \& K.-H. Schleifer. New York: Springer.

Balch, W. E., Fox, G. E., Magrum, L. J., Woese, C. R. \& Wolfe, R. S. (1979). Methanogens: re-evaluation of a unique biological group. Microbiol Rev 43, 260-296.
Bonjour, F. \& Aragno, M. (1986). Growth of thermophilic, obligatorily chemolithoautotrophic hydrogen-oxidizing bacteria related to Hydrogenobacter with thiosulfate and elemental sulfur as electron and energy source. FEMS Microbiol Lett 35, 11-15.

Burggraf, S., Olsen, G. J., Stetter, K. O. \& Woese, C. R. (1992). A phylogenetic analysis of Aquifex pyrophilus. Syst Appl Microbiol 15, 352-356.

Felsenstein, J. (1989). PHYLIP - phylogeny inference package (version 3.2). Cladistics 5, 164-166.

Hayashi, N. R., Ishida, T., Yokota, A., Kodama, T. \& Igarashi, Y. (1999). Hydrogenophilus thermoluteolus gen. nov., sp. nov., a thermophilic, facultatively chemolithoautotrophic, hydrogenoxidizing bacterium. Int J Syst Bacteriol 49, 783-786.

Huber, R., Wilharm, T., Huber, D. \& 7 other authors (1992). Aquifex pyrophilus gen. nov., sp. nov., represents a novel group of marine hyperthermophilic hydrogen-oxidizing bacteria. Syst Appl Microbiol 15, 340-351.

Huber, R., Eder, W., Heldwein, S., Wanner, G., Huber, H., Rachel, R. \& Stetter, K. O. (1998). Thermocrinis ruber gen. nov., sp. nov., a pink-filament-forming hyperthermophilic bacterium isolated from Yellowstone National Park. Appl Environ Microbiol 64, 3576-3583.

Ishii, M., Kawasumi, T., Igarashi, Y., Kodama, T. \& Minoda, Y. (1983). 2-Methylthio-1,4-naphthoquinone, a new quinone from an extremely thermophilic hydrogen bacterium. Agric Biol Chem 47, 167-169.

Ishii, M., Kawasumi, T., Igarashi, Y., Kodama, T. \& Minoda, Y. (1987). 2-Methylthio-1,4-naphthoquinone, a unique sulfurcontaining quinone from a thermophilic hydrogen-oxidizing bacterium, Hydrogenobacter thermophilus. J Bacteriol 169, $2380-2384$.

Jukes, T. H. \& Cantor, C. R. (1969). Evolution of protein molecules. In Mammalian Protein Metabolism, pp. 21-132. Edited by H. N. Munro. New York: Academic Press.

Kawasumi, T., Igarashi, Y., Kodama, T. \& Minoda, Y. (1984). Hydrogenobacter thermophilus gen. nov., sp. nov., an extremely thermophilic, aerobic, hydrogen-oxidizing bacterium. Int J Syst Bacteriol 34, 5-10.

Kristjansson, J. K., Ingason, A. \& Alfredsson, G. A. (1985). Isolation of thermophilic obligately autotrophic hydrogen oxidizing bacteria, similar to Hydrogenobacter thermophilus, from Icelandic hot springs. Arch Microbiol 140, 321-325.

Kryukov, V. R., Savel'eva, N. D. \& Pusheva, M. A. (1983). Calderobacterium hydrogenophilum nov. gen., nov. sp., an extreme thermophilic hydrogen bacterium, and its hydrogenase activity. Mikrobiologiya 52, 781-788.

Mesbah, M., Premachandran, U. \& Whitman, W. B. (1989). Precise measurement of the $\mathrm{G}+\mathrm{C}$ content of deoxyribonucleic acid by high-performance liquid chromatography. Int $J$ Syst Bacteriol 39, 159-167.

Nishihara, H., Igarashi, Y. \& Kodama, T. (1990). A new isolate of Hydrogenobacter, an obligately chemolithotrophic, thermophilic, halophilic and aerobic hydrogen-oxidizing bacterium from seaside saline hot spring. Arch Microbiol 153, 294-298.

Olsen, G. J., Larsen, N. \& Woese, C. R. (1991). The ribosomal RNA database project. Nucleic Acids Res 19 (Suppl.), 2017-2021.

Reynolds, E. S. (1963). The use of lead citrate at high $\mathrm{pH}$ as an electron-opaque stain in electron microscopy. $J$ Cell Biol 17, 208-212. 
Reysenbach, A.-L., Wickham, G. S. \& Pace, N. R. (1994). Phylogenetic analysis of the hyperthermophilic pink filament community in Octopus Spring, Yellowstone National Park. Appl Environ Microbiol 60, 2113-2119.

Reysenbach, A.-L., Banta, A. B., Boone, D. R., Cary, S. C. \& Luther, G. W. (2000). Microbial essentials at hydrothermal vents. Nature 404, 835.

Shima, S. \& Suzuki, K. (1993). Hydrogenobacter acidophilus $\mathrm{sp.}$ nov., a thermoacidophilic, aerobic, hydrogen-oxidizing bacterium requiring elemental sulfur for growth. Int $J$ Syst Bacteriol 43, 703-708.

Stöhr, R., Waberski, A., Liesack, W., Völker, H., Wehmeyer, U. \& Thomm, M. (2001). Hydrogenophilus hirschii sp. nov., a novel thermophilic hydrogen-oxidizing $\beta$-proteobacterium isolated from Yellowstone National Park. Int J Syst Evol Microbiol 51, 481-488.

Thompson, J. D., Higgins, D. G. \& Gibson, T. J. (1994). CLUSTAL $\mathrm{W}$ : improving the sensitivity of progressive multiple sequence alignment through sequence weighting, position-specific gap penalties and weight matrix choice. Nucleic Acids Res 22, 4673-4680.

Tindall, B. J. (1990a). A comparative study of the lipid composition of Halobacterium saccharovorum from various sources. Syst Appl Microbiol 13, 128-130.

Tindall, B. J. (1990b). Lipid composition of Halobacterium lacusprofundi. FEMS Microbiol Lett 66, 199-202.

ZoBell, C. E. (1941). Studies on marine bacteria. I. The cultural requirements of heterotrophic aerobes. J Mar Res 4, 42-75. 